\title{
SPATIAL AND ECONOMIC DETERMINANTS OF DIFFERENT FOOD CONSUMPTION PATTERNS AROUND THE WORLD
}

\author{
Arkadiusz Sadowski ${ }^{\bowtie}$ \\ Poznań University of Life Sciences, Poland
}

\begin{abstract}
This paper addresses the spatial differentiation of food consumption patterns. The objective is to identify the economic and natural determinants of consumption levels and of differences in foodstuffs consumed around the world in the 2000s. The study was based on data delivered by FAOSTAT and the World Bank. An analysis was performed of global correlation trends between economic factors (GDP per capita), natural and geographic factors (agricultural land per capita, and the food availability status. Also, cluster analysis was used to group the countries around the world by percentage share of plant, animal and aquaculture products in the dietary energy consumption ( $\mathrm{kcal} / \mathrm{capita} / \mathrm{day}$ ), and by agricultural land per capita. Based on the analyses, the economic factor was found to significantly prevail as a determinant of food security for different nations. The size of the dietary energy consumption and the share of animal products in it depend primarily on the domestic product per capita. Also noticed was the relatively low importance of natural conditions, expressed in this paper as agricultural land per capita. Based on previous research, the suitability of land for agricultural purposes was found to be historically important for human settlement around the world, though currently it is not the key determinant of food security. Also, the importance of aquaculture in addressing the global population's food needs was found to be marginal though spatially differentiated.
\end{abstract}

Keywords: food security around the world, spatial differentiation of food consumption

\section{INTRODUCTION}

Addressing the food needs is among the basic and strategic aspects of living for both individuals and societies. Since the Neolithic Revolution, the vast majority of food consumed has been produced by agriculture, and the importance of hunting and aquaculture has gradually become marginalized. The specific nature of the agricultural sector is reflected by the interaction between environmental and anthropogenic factors which may turn into cooperation or conflict. Equally important, both the environmental and civilization conditions differ greatly around the world. Soil quality, landscape and weather patterns vary from one part of the globe to another, and so does agricultural land per capita. This is also true for factors resulting from human activity, including the outcomes of the multidimensional progress of agriculture driven by land improvement, mechanization, wide use of chemicals, genetics, or production organization methods. The anthropogenic aspects mainly depend on the development level of the community concerned which may be roughly defined as domestic product per capita. Note that the objectives of human (social) contribution to agricultural production include the modification of space which means, to some extent, the minimization of certain natural aspects with an adverse impact on food production. Foreign trade is another matter of importance, especially in the modern era.

\footnotetext{
$\llbracket$ Arkadiusz Sadowski, PhD hab., Department of Economics and Economic Policy in Agribusiness, Poznań University of Life Sciences, Wojska Polskiego 28 St., 60-637 Poznań, Poland, e-mail: sadowski@up.poznan.pl, https://orcid.org/0000-0002-8236-1007
} 
An appropriate level of wealth makes it possible-even without overcoming natural disadvantages - to address the food needs through imports. Note however that it involves a great political risk of becoming dependent upon other communities.

Having the above in mind, a need emerges to assess the importance of today's natural and civilization factors for addressing the food needs of different countries. Therefore, the objective of this paper is to identify the economic and natural determinants of consumption levels and of differences in foodstuffs consumed around the world in the 2000s.

\section{METHODOLOGY}

This study was primarily based on variables retrieved from the Faostat (www.faostat.fao.org). The population, agricultural land area, dietary energy consumption (kcal per capita a day) and the share of plant, animal and aquaculture products in dietary energy consumption was the data used in this study. Necessary data was supplemented with information on GDP per capita from the World Bank (www.worldbank.org).

For the countries under review, the categories were defined as the mean level recorded in 2000-2013. This approach was adopted to avoid one-year fluctuations affecting the developments under consideration. The study covered all countries around the world with a population above 1 million for which essential statistical data was readily available.

The analyses relied on two fundamental statistical methods. The first one is correlation which examines the strength of relationships between variables; in this case, the economic factor (GDP in USD per capita), the natural and spatial factor (agricultural land in hectares per capita), consumption (kcal per capita) and its structure (share of plant, animal and aquaculture products) are the variables considered. Due to the synthetic nature of the research, qualitative characteristics of the diet, such as the amount of protein, fat or micronutrients consumed, were not taken into account. It was recognized that the basic function of food is to provide the right amount of energy for the human body.

The second one is the k-means cluster analysis performed with the Statistica 13.1 software suite. The countries were grouped by percentage share of plant, animal and aquaculture products in the dietary energy consumption, and by agricultural land (ha per capita).
These features were chosen because they provide a synthetic picture of the consumption structure while referring to food production capacity.

The k-means method consists in grouping objects into a predefined number of clusters so that objects within a cluster demonstrate the highest similarity to each other while differing as much as possible from those arranged in other clusters (Stanisz, 2007). In line with the calculation procedure, the objects are clustered randomly and are afterwards successively moved by the algorithm from one cluster to another so as to minimize intra-cluster variation while maximizing inter-cluster variation. This method was chosen because the research assumption was to determine a definite and relatively small number of clusters of countries differing in terms of the characteristics used. Certainly, it has its limitations, primarily because the relative uniformity of clusters in terms of the characteristics examined does not necessarily reflect their homogeneity with respect to other features.

Obviously, the scope of this study does not fully address the complexity of the problem which - just as most socio-economic issues - is manifested by multifaceted relationships of various strength which varies from one development stage to another. GDP per capita is not the only way to measure the country's economic development level. For instance, it fails to take account of income disparities. Similarly, agricultural land per capita cannot be regarded as the only and ultimate measure of natural conditions for agricultural production because it fails to consider some important aspects, such as the quality of production space. Nevertheless, the above approach was used because both yardsticks give a synthetic account of national wealth and of the environmental potential for the production of raw materials necessary to provide food for the population of the country concerned.

\section{RESULTS AND DISCUSSION}

The correlation coefficient - reflecting the strength of relationships between different parameters of food availability status and its selected natural and economic determinants - shows that economic aspects play a much more important role (Table 1). An absolute value beyond 0.5 was obtained for the correlation between the energy consumed and the share of plant and animal products in the dietary energy consumption, on one side, 
Table 1. Correlation between food security and economic and natural factors around the world

\begin{tabular}{|c|c|c|c|c|c|c|}
\hline Specification & $\begin{array}{l}\text { GDP per capita } \\
\text { (USD) }\end{array}$ & $\begin{array}{l}\text { Agricultural } \\
\text { land per capita } \\
\text { (ha) }\end{array}$ & $\begin{array}{c}\text { Total daily } \\
\text { energy con- } \\
\text { sumption (kcal/ } \\
\text { person/day) }\end{array}$ & $\begin{array}{l}\text { Share of energy } \\
\text { from animal } \\
\text { products }(\%)\end{array}$ & $\begin{array}{l}\text { Share of en- } \\
\text { ergy from plant } \\
\text { products }(\%)\end{array}$ & $\begin{array}{l}\text { Share of energy } \\
\text { from fishery } \\
\text { and aquaculture } \\
\text { products (\%) }\end{array}$ \\
\hline GDP per capita (USD) & 1.00 & $\mathrm{x}$ & $\mathrm{x}$ & $\mathrm{x}$ & $\mathrm{x}$ & $\mathrm{x}$ \\
\hline $\begin{array}{l}\text { Agricultural land per capita } \\
\text { (ha) }\end{array}$ & -0.05 & 1.00 & $\mathrm{x}$ & $\mathrm{x}$ & $\mathrm{x}$ & $\mathrm{x}$ \\
\hline $\begin{array}{l}\text { Total daily energy con- } \\
\text { sumption (kcal/person/day) }\end{array}$ & 0.65 & -0.13 & 1.00 & $\mathrm{x}$ & $\mathrm{x}$ & $\mathrm{x}$ \\
\hline $\begin{array}{l}\text { Share of energy from } \\
\text { animal products }(\%)\end{array}$ & 0.67 & 0.18 & 0.66 & 1.00 & $\mathrm{x}$ & $\mathrm{x}$ \\
\hline $\begin{array}{l}\text { Share of energy from plant } \\
\text { products }(\%)\end{array}$ & -0.69 & -0.16 & -0.67 & -1.00 & 1.00 & $\mathrm{x}$ \\
\hline $\begin{array}{l}\text { Share of energy from } \\
\text { fishery and aquaculture } \\
\text { products }(\%)\end{array}$ & 0.35 & -0.14 & 0.20 & 0.09 & -0.18 & 1.00 \\
\hline
\end{tabular}

Source: own calculations based on www.faostat.fao.org

and GDP per capita on the other. Agricultural land per capita proved to be statistically insignificant in that respect. A positive correlation was also observed between the amount of energy consumed and the share of animal products in the diet. Other significant dependencies are the mathematical opposites of those described above. This means that in today's globalized economy, the ability to provide food depends much more on national wealth than on geographic and natural conditions, as also noted by Dec et al. (2008) and Pawlak 2016.

Historically, it was quite the opposite (Landes, 1998; Sadowski, 2017): civilizations emerged primarily in regions characterized by favorable natural conditions enabling an effective and stable agricultural production. To this day, such regions exhibit a considerably higher population density, as may be observed in Europe or Southeast Asia, for instance. However, the historical process which shaped today's world is one thing, and the current conditions are another. From the perspective of the topic discussed in this paper, today's economy has two important features. The first one is the growing importance of physical and human capital as a crucial factor of development. The second one is globalization which makes the national economies increasingly open (Kołodko, 2008). These conditions also have an impact on food and agriculture. First of all, the multifaceted progress of agriculture (primarily involving the mechanical, chemical and biological aspects) contributed to a situation where the farmers' capital and knowledge (which, in practice, depend on national wealth measured for instance with the GDP per capita ratio) are increasingly decisive for the production capacity. Furthermore, the opening of economies enables supplementing the domestic agricultural production with imports. This is especially true for wealthy countries affected by unfavorable agricultural conditions, as illustrated by the example of Japan. Note however that agricultural production is related to the strategic issue of food security, and therefore in most countries around the world, an import-based domestic consumption will not be the prevailing option.

The above global trends, determined based on correlations between different processes, were also reflected in the classification of countries based on cluster analysis (Table 2, Fig. 1). Obviously, the complexity of local and global conditions is the reason for certain exceptions to the general rules which are an indirect manifestation of the geographic diversification of today's agri-food economy conditions. The clustering was based on noneconomic criteria which included the structure of energy consumed and agricultural land per capita. Nevertheless, some clear differences exist between the development levels of countries arranged in specific clusters. 
Sadowski, A. (2019). Spatial and economic determinants of different food consumption patterns around the world. J. Agribus. Rural Dev., 1(51), 69-76. http://dx.doi.org/10.17306/J.JARD.2019.01109

Table 2. Countries grouped by agricultural land per capita (ha) and energy consumed (kcal/person/day)

\begin{tabular}{|c|c|c|c|}
\hline Cluster 1 & Cluster 2 & Cluster 3 & Cluster 4 \\
\hline Austria & Albania & Armenia & Angola \\
\hline Belgium & Algeria & Bangladesh & Bolivia \\
\hline Canada & Argentina & Benin & Botswana \\
\hline Denmark & Australia & Bulgaria & Burundi \\
\hline Egypt & Azerbaijan & Burkina Faso & Cambodia \\
\hline France & Belarus & Colombia & Cameroon \\
\hline Germany & Bosnia and Herzegovina & Costa Rica & Central African Republic \\
\hline Greece & Brazil & Ivory Coast & Chad \\
\hline Hungary & Chile & Dominican Republic & Congo \\
\hline Ireland & China & El Salvador & Ecuador \\
\hline Israel & Croatia & Gambia & Guatemala \\
\hline Italy & Cuba & Georgia & Guinea-Bissau \\
\hline Kuwait & Estonia & Ghana & Haiti \\
\hline Lithuania & Finland & Guinea & India \\
\hline Norway & Iran & Honduras & Kenya \\
\hline Poland & Jordan & Indonesia & Lao People's Democratic Republic \\
\hline Portugal & Kazakhstan & Jamaica & Liberia \\
\hline Romania & Latvia & Japan & Madagascar \\
\hline Switzerland & Lebanon & Kyrgyzstan & Malawi \\
\hline Tunisia & Libya & Lesotho & Mongolia \\
\hline Turkey & Mauritius & Malaysia & Mozambique \\
\hline United Kingdom & Mexico & Mali & Namibia \\
\hline United States of America & Morocco & Mauritania & Niger \\
\hline \multirow[t]{18}{*}{ Luxembourg } & Netherlands & Myanmar & Pakistan \\
\hline & New Zealand & Nepal & Rwanda \\
\hline & Republic of Korea & Nicaragua & Senegal \\
\hline & Russian Federation & Nigeria & Sierra Leone \\
\hline & Saudi Arabia & Panama & Sudan (former) \\
\hline & Slovenia & Paraguay & Tajikistan \\
\hline & South Africa & Peru & Togo \\
\hline & Spain & Philippines & Uganda \\
\hline & Sweden & Republic of Moldova & United Republic of Tanzania \\
\hline & Syria & Slovakia & Yemen \\
\hline & Macedonia & Sri Lanka & Zambia \\
\hline & Ukraine & Thailand & Zimbabwe \\
\hline & United Arab Emirates & Trinidad and Tobago & \\
\hline & Czech Republic & Turkmenistan & \\
\hline & & Uruguay & \\
\hline & & Uzbekistan & \\
\hline & & Venezuela & \\
\hline & & Viet Nam & \\
\hline
\end{tabular}

Source: own study based on www.faostat.fao.org 


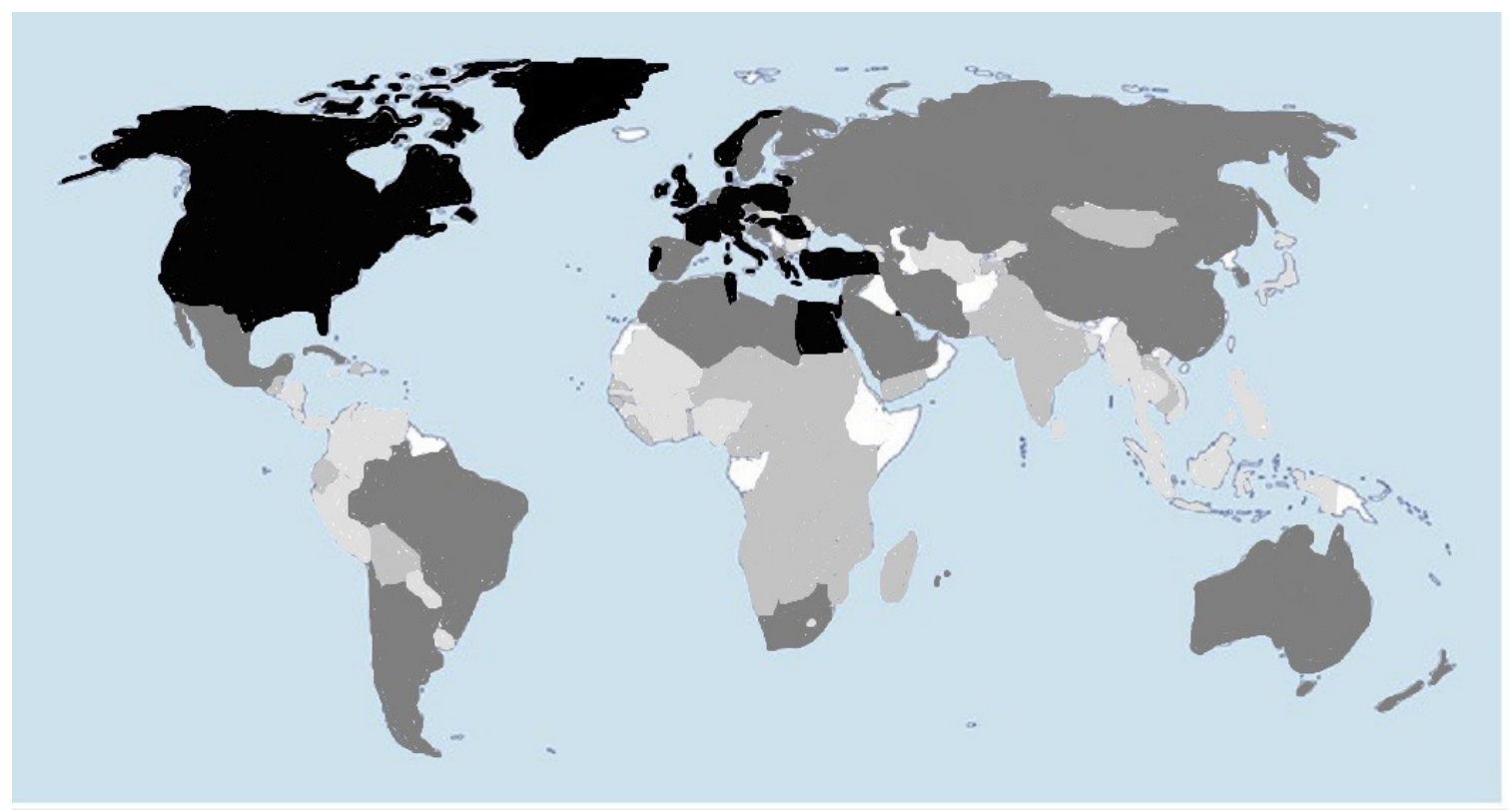

Fig. 1. Geographic location of countries grouped in different clusters

\begin{tabular}{|c|c|c|c|c|}
\hline $\begin{array}{c}\text { Cluster } 1 \\
\text { The richest countries }\end{array}$ & $\begin{array}{c}\text { Cluster } 2 \\
\text { Average wealthy } \\
\text { countries }\end{array}$ & $\begin{array}{c}\text { Cluster } 3 \\
\text { Poor countries }\end{array}$ & $\begin{array}{c}\text { Cluster } 4 \\
\text { The poorest countries }\end{array}$ & No data \\
\hline
\end{tabular}

Source: own calculations based on www.faostat.fao.org

This is especially true for cluster 1, mainly composed of wealthy European and North American countries. They are inhabited by slightly more than $14 \%$ of the world's population and demonstrate a similar share of agricultural land but account for more than a half of the global GDP (Table 3). As a consequence, they represent the highest level of GDP per capita of all clusters (Table 4). They also report the highest amounts of energy consumed despite a relatively small area of agricultural land per capita. This is consistent with the previous discussion on the decisive impact of economic factors on food security. Note also that European countries are not only food secure but also self-sufficient in basic agri-food products (Baer-Nawrocka, 2014). Another interesting finding is that this cluster demonstrates the highest share of animal products in the dietary energy consumption. For centuries, high levels of meat, milk and egg consumption have been an attribute of wealth. Note however that these countries deal with a relatively small area of agricultural land per capita while the
Table 3. Importance of countries arranged in different clusters (world $=100)$

\begin{tabular}{lccc}
\hline \multicolumn{1}{c}{ Cluster } & Population & $\begin{array}{c}\text { Utilized } \\
\text { agricultural area }\end{array}$ & GDP \\
\hline $\begin{array}{l}\text { The richest countries } \\
\begin{array}{l}\text { Average wealthy } \\
\text { countries }\end{array}\end{array}$ & 14.3 & 14.4 & 54.7 \\
$\begin{array}{l}\text { Poor countries } \\
\begin{array}{l}\text { The poorest } \\
\text { countries }\end{array}\end{array}$ & 20.6 & 52.5 & 28.1 \\
\hline
\end{tabular}

Source: own calculations based on www.faostat.fao.org

production of adequate quantities of energy from animal products requires a much larger area than in the case of plant products. This is related to the conversion of energy stored in feed to energy stored in animal tissue (Zegar, 2012). Nevertheless, excessive consumption of 
Table 4. Natural and economic aspects of food security in countries around the world arranged in groups

\begin{tabular}{lcccccc}
\hline \multicolumn{1}{c}{ Cluster } & $\begin{array}{c}\text { GDP per capita } \\
\text { (USD) }\end{array}$ & $\begin{array}{c}\text { Agricultural land } \\
\text { per capita } \\
\text { (ha) }\end{array}$ & $\begin{array}{c}\text { Total daily } \\
\text { energy } \\
\text { consumption } \\
\text { (kcal/person/day) }\end{array}$ & $\begin{array}{c}\text { Share } \\
\text { of energy from } \\
\text { animal products } \\
(\%)\end{array}$ & $\begin{array}{c}\text { Share } \\
\text { of energy from } \\
\text { plant products } \\
(\%)\end{array}$ & $\begin{array}{c}\text { Share of energy } \\
\text { from fishery } \\
\text { and aquaculture } \\
\text { products } \\
(\%)\end{array}$ \\
\hline $\begin{array}{l}\text { The richest } \\
\text { countries }\end{array}$ & 31,663 & 0.75 & 3,539 & 23.5 & 75.6 & 1.0 \\
$\begin{array}{l}\text { Average wealthy } \\
\text { countries }\end{array}$ & 6,216 & 1.04 & 3,027 & 19.4 & 79.3 & 1.3 \\
$\begin{array}{l}\text { Poor countries } \\
\begin{array}{l}\text { The poorest } \\
\text { countries }\end{array}\end{array}$ & 5,587 & 0.43 & 2,583 & 9.0 & 89.2 & 1.8 \\
\hline
\end{tabular}

Source: own calculations based on www.faostat.fao.org

animal products may cause health problems and affect the environment (Kwasek and Obiedzińska, 2014).

Cluster 2 includes a large part of Asia, Latin America, North and South Africa, and several wealthy countries, such as Spain, Sweden, Norway and Australia (Fig. 1, Table 2). Usually, these are countries with a low population density and with the largest area of agricultural land per capita of all types under review. They account for more than a half of the world's agricultural land while being inhabited by only around $37 \%$ of the global population. Their contribution to GDP reaches an even lower level of $28 \%$ (Table 3). This means that, beside some exceptions mentioned earlier, this group is mainly composed of medium-income countries. Though the average GDP per capita considerably differs from that recorded in cluster 1 , the dietary energy consumption is only a bit lower. The share of animal products in the diet is also quite high, especially compared to clusters 3 and 4 . This can result from two fundamental causes. The first one refers to the natural and geographic specificity and is related to the large area of agricultural land per capita. As mentioned earlier, the productivity of today's world agriculture is increasingly dependent on capital resources and expenditure, and becomes gradually independent from natural conditions. However, it does not mean the above is equally true across the globe. Cluster 2 countries have relatively more land than capital, and therefore their strategy is based on a quite extensive use of agricultural land. The above gives rise to a question on what would be the agricultural productivity of these countries if they had enough capital to intensify their production. How much of the world's population could then be fed and what would be the environmental impact? The second reason for the relatively good availability of food in these countries in a context of low average incomes is the very essence of food which addresses the basic, irreducible needs of individuals and whole societies (Paszkowski, 2015). Therefore, even if a country has relatively poor capital resources and generates a small GDP, the society and the government are committed to food security, especially if large areas provide opportunities for agricultural use (even if based on extensive practices). Though the above is true for the cluster as a whole, some quite significant exceptions exist. The most important one is China where the size and structure of the dietary energy consumption is similar to that of other countries in this cluster but the area of agricultural land per capita is small. Another example is Spain which demonstrates a relatively high income.

Cluster 3 includes India, numerous African countries and several South American countries (Fig. 1, Table 2). Though they are home to over $20 \%$ of the global population, they hold less than $12 \%$ of the global agricultural area (Table 3). As a consequence, they have the smallest area of agricultural land of all the clusters under consideration (Table 4). Note also that these are not wealthy countries as their population generates only less than $14 \%$ of the global GDP, and the per capita ratio is lower than in cluster 2. The lack of sufficient capital and land resources makes it harder for them to produce enough food for the population. In this cluster, a large part of countries face nutrition problems (Caparós, 2014; FAO, 
2012; 2014; Gulbicka, 2009; Sachs, 2005; Sadowski and Baer-Nawrocka, 2018). The average dietary energy consumption is $2583 \mathrm{kcal}$ (nearly $1000 \mathrm{kcal}$ less than in cluster 1), and is composed of nearly 90 percent of plant products. Interestingly, compared to other clusters, these countries exhibit a relatively high share of aquaculture products. Accessing food products from outside the agriculture sector, though rarely practiced, is a kind of remedy to the aforesaid shortage of capital and land. Japan is a prominent exception. Because mountains prevail in the landscape and the country has a large population, there is a small area of agricultural land per capita. Moreover, the low-calorie diet results from a specific culinary tradition. What makes Japan different from other cluster 3 countries is the level of wealth which means, in practice, that the country is fully food secure. This example shows that natural disadvantages may be overcome, and that an effectively functioning society and economy may be built to address the most pressing needs.

Cluster 4 includes countries located in Western Africa, Southeast Asia and South America (Fig. 1, Table 2) which are home to over $27 \%$ of the global population and generate slightly more than $3 \%$ of the global GDP (Table 3). Moreover, the share of agricultural land is lower than the share of population. On the one hand, this means the lowest level of income per capita of all the clusters under review, and one of the smallest areas of agricultural land per capita (Table 4). This situation is similar to that of cluster 3 , except that poverty is experienced to a greater degree. As a consequence, the average dietary energy consumption is the lowest of all clusters, and is composed of over 90 percent of plant products while aquaculture products are of marginal importance. Compared to cluster 1, the energy consumed is lower by more than $1000 \mathrm{kcal}$ (around 1/3). However, compared to cluster 3 , the difference is considerably lower, even despite quite large disparities in wealth. Once again, this shows the specific function of food and the strategic importance of food security which should be ensured in the first place.

Despite some considerable differences in the size and structure of the dietary energy consumption, all clusters under review share several similar aspects. Most notably, in all clusters, the amount of kilocalories consumed is not lower than 2,000 and only slightly greater than 3,500 . This is quite an important difference, especially as the figures considered are average levels; for some poor countries, this could mean food problems. Nevertheless, the values fall within the limits of human daily demand for energy which, according to Gulbicka (2013), ranges from 2,200 to $2,800 \mathrm{kcal}$. This results directly from the specificity of human physiology, while also pointing to the key role of food which must be produced at least in minimum quantities. Equally symptomatic is the role of plant products which prevail in the dietary energy consumption of all clusters under consideration. This results from the dietary specifics which have developed since the advent of agriculture in the Neolithic Age where humans gradually shifted from food based on hunted animal proteins to one based on carbohydrates obtained primarily from cereal grains (Grzebisz and Szramka, 1998). Though a difference in the share of animal products exists between poor and wealthy countries (and between poor and wealthy members of the public), plant products prevail in all cases, exceeding $75 \%$ of the daily energy demand in each cluster. Equally symptomatic is the marginal importance of aquaculture products which is close to $2 \%$ only in cluster 3 . The highest consumption levels of aquaculture products is reported in Japan; but even there they address only $5.4 \%$ of demand. This means that today, globally, the agriculture is responsible for fulfilling nearly all nutritional needs of the human population.

\section{SUMMARY}

This research directly addressed the food availability status of different countries and parts of the world, while indirectly referring to problems affecting agriculture as the sector responsible for the production of foodstuffs. Primarily, it indicates the prevailing importance of the economic factor which is decisive for the level of food security. High income levels enable the development of an agricultural model which is capital-intensive and efficient at the same time. Moreover, it also enables importing food if natural conditions are unfavorable which, however, is rarely the case because of the strategic function of food. From the spatial development perspective, the conclusion is that as the civilization progresses and, consequently, as wealth inequality between societies is getting wider (Acemoglu and Robinson, 2012), agricultural production becomes increasingly affected by artificial (man-made) boundaries whereas the impact of natural boundaries (which delimit the areas suitable for agricultural production) becomes ever smaller. In this context, note that artificial boundaries are usually strictly defined while natural ones are of a fuzzy nature. In turn, from the historical perspective, agricultural 
development consists to a large extent in an increase in the importance of the human factor at the expense of environmental factors. However, at least at the current stage of development, the above does not mean the environmental factors are negligible. The use of productive inputs such as fertilizers, plant protection products or certified seed is more efficient in regions suitable for agricultural production. Also, as mentioned in this paper, historically, agricultural development was particularly intense in regions highly conducive to production activities which is reflected today by high population density. Note however that these regions are home to both wealthy and relatively poor countries, but only the first ones are capable of ensuring complete or nearly complete food security. In densely populated poor countries, agricultural production is enabled by geographical and natural conditions, and is necessary because of demographic pressures. However, their development level often makes true food security impossible.

\section{SOURCE OF FINANCING}

This paper was financed from the research fund of the Department of Economics and Economic Policy in Agribusiness at the Faculty of Economics and Social Sciences, Poznań University of Life Sciences.

\section{REFERENCES}

Acemoglu, D., Robinson, J. A. (2012). Why Nations fail. The origins of power, prosperity and poverty. Crown Business.

Caparós, M. (2014). El Hambre. Anagrama.

Baer-Nawrocka, A. (2014). Zmiany w spożyciu i stopniu samowystarczalności żywnościowej w Unii Europejskiej (Changes in consumption and food self-sufficiency in the European Union). Res. Pap. Wroc. Univ. Econ., 360, 19-27.

Dec, M., Pawlak, K., Poczta, W. (2008). Determinanty sytuacji wyżywieniowej ludności Świata [Determinants of food availability status around the world]. Wieś Roln., 2, 9-25.

FAO (2012). FAO statistical pocketbook. Rome: FAO.

FAO (2014). The state od food insecurity in the world. Rome: FAO.

FAOSTAT (n.d.). Retrieved March 292018 from: www.faostat.fao.org

Grzebisz, W., Szramka, H. (1998). Rolnictwo i leśnictwo. Wielka encyklopedia geografii świata [Agriculture and forestry. The great encyclopedia of world geography] (vol. XI). Poznań: Kurpisz.

Gulbicka, B. (2009). Problemy wyżywienia w krajach rozwijających się [Food problems in developing countries]
Warsaw: Institute of Agricultural and Food Economics the National Research Institute.

Gulbicka, B. (2013). Problemy wyżywienia ludności na kontynencie afrykańskim [Problems of feeding the African population]. Warsaw: Institute of Agricultural and Food Economics - the National Research Institute.

Kołodko, G. (2008). Wędrujący świat [The migrant world]. Warsaw: Prószyński i S-ka.

Kwasek, M., Obiedzińska, A. (2014). Zrównoważone systemy rolnicze i zrównoważona dieta [Sustainable agricultural systems and a sustainable diet]. Warsaw: Institute of Agricultural and Food Economics - the National Research Institute.

Landes, D. (1998). The wealth and poverty of the nations. Why some are so rich and some so poor. New York: W. W. Norton \& Company.

Paszkowski, S. (2015). Problemy światowego i europejskiego bezpieczeństwa żywnościowego [Global and European food security problems]. In: A. Czyżewski, B. Klepacki (Eds.), Problemy rozwoju rolnictwa i gospodarki żywnościowej w pierwszej dekadzie członkostwa Polski w Unii Europejskiej [Problems of the development of agriculture and food economics encountered in the first decade of Poland's membership in the European Union] (p. 363-384). Warszawa: PTE.

Pawlak, K. (2016). Food security situation of selected highly developed countries against developing countries. J. Agribus. Rural Dev., 2(40), 385-398, doi: 10.17306/ JARD. 2016.42

Sachs, J. (2005). The end of poverty. How we can make it happen in our lifetime. London: Penguin Books.

Sadowski, A. (2017). Wyżywieniowe i środowiskowe funkcje światowego rolnictwa - analiza ostatniego półwiecza [Nutritional and environmental functions of global agriculture: an analysis of the last five decades]. Poznań: Wydawnictwo Uniwersytetu Przyrodniczego w Poznaniu.

Sadowski, A., Baer-Nawrocka, A. (2018). Food and environmental function in world agriculture - Interdependence or competition? Land Use Policy, 71, 578-583, https://doi. org/10.1016/j.landusepol.2017.11.005

Stanisz, A. (2007). Przystępny kurs statystyki z zastosowaniem STATISTICA PL na przykładzie medycyny [An accessible statistics course based on STATISTICA.PL illustrated by medical examples] (vol. 3). Multidimensional analyses. Kraków: Statsoft.

WorldBank (n.d.). Retrieved March 292018 from: www. worldbank.org

Zegar, J. S. (2012). Współczesne wyzwania rolnictwa [Challenges of modern agriculture]. Warszawa: Wyd. Nauk. PWN. 